\title{
Correction to: Multiple phenotypic traits as triggers of host attacks towards ant symbionts: body size, morphological gestalt, and chemical mimicry accuracy
}

\author{
Christoph von Beeren ${ }^{1 *}\left(\mathbb{0}\right.$, Adrian Brückner ${ }^{2}$, Philipp O. Hoenle ${ }^{1}$, Bryan Ospina-Jara ${ }^{3}$, \\ Daniel J. C. Kronauer ${ }^{4}\left[\right.$ and Nico Blüthgen ${ }^{1}$
}

\section{Correction to: Front Zool (2021) 18:46 https://doi.org/10.1186/s12983-021-00427- 8}

Following publication of the original article [1], some errors were found in the online article:

On page 3: in the Fig. 1 caption, the text following (B) and (C) need to be swapped. It should read: '(A) Ecitophya rove beetle representing the myrmecoid gestalt, (B) Vatesus rove beetle as well as (C) Nymphister histerid beetle the protective gestalt, (D) Vatesus rove beetle larva ....

On page 8: in the section of 'Comparisons across ecitophile phenotypic traits', the sentence 'This study included six species with such a gestalt (Table 2).' should be 'This study included eight species with such a gestalt (Table 2).'

On Page 11, in the section of 'Comparisons across ecitophile phenotypic traits', the citation in the sentence 'Unexpectedly, we found no clear overall effect of $\mathrm{CHC}$ host similarity on host aggression (Table 2)' is incorrect, the citation should be 'Table 3, so the whole sentence will be: Unexpectedly, we found no clear overall effect of $\mathrm{CHC}$ host similarity on host aggression (Table 3).'

On page 14, the word 'occurred' was missed in the sentence of 'For instance, these miniature ecitophiles efficiently avoided contacts with ants by moving away promptly in their typical stop-and-go, zigzag manner, often before physical contact even', the whole sentence should be: 'For instance, these miniature ecitophiles efficiently avoided contacts with ants by moving away promptly in their typical stop-and-go, zigzag manner, often before physical contact even occurred.'

The original paper has been updated.

The Publisher apologizes to the authors and the readers for the inconvenience caused by the errors. 


\section{Author details}

${ }^{1}$ Technical University of Darmstadt, Darmstadt, Germany. ${ }^{2}$ Division of Biology and Biological Engineering, California Institute of Technology, Pasadena, USA. ${ }^{3}$ Department of Biology, University of Valle, Cali, Colombia. ${ }^{4}$ Laboratory of Social Evolution and Behav- Ior, The Rockefeller University, New York City, USA.

Published online: 11 January 2022

\section{Reference}

1. von Beeren C, Brückner A, Hoenle PO, Ospina-Jara B, Kronauer DJC, Blüthgen N. Multiple phenotypic traits as triggers of host attacks towards ant symbionts: body size, morphological gestalt, and chemical mimicry accuracy. Front Zool. 2021;18:46. https://doi.org/10.1186/s12983-021-00427-8.

\section{Publisher's Note}

Springer Nature remains neutral with regard to jurisdictional claims in published maps and institutional affiliations.
Ready to submit your research? Choose BMC and benefit from:

- fast, convenient online submission

- thorough peer review by experienced researchers in your field

- rapid publication on acceptance

- support for research data, including large and complex data types

- gold Open Access which fosters wider collaboration and increased citations

- maximum visibility for your research: over 100M website views per year

At BMC, research is always in progress.

Learn more biomedcentral.com/submissions 